\title{
Interaction between nutrients and herbivory in controlling algal communities and coral condition on Glover's Reef, Belize
}

\author{
T. R. McClanahan ${ }^{1,5, *}$, E. Sala1,2, P. A. Stickels ${ }^{3}$, B. A. Cokos $^{3}$, A. C. Baker ${ }^{1,3}$, \\ C. J. Starger ${ }^{3}$, S. H. Jones IV ${ }^{4}$ \\ ${ }^{1}$ Wildlife Conservation Society, International Programs, 2300 Southern Boulevard, Bronx, New York 10460, USA \\ ${ }^{2}$ Center for Marine Biodiversity and Conservation, Scripps Institution of Oceanography, La Jolla, California 92093, USA \\ ${ }^{3}$ Center for Environmental Research and Conservation, Columbia University, 1200 Amsterdam Avenue, New York, \\ New York 10027, USA \\ ${ }^{4}$ Osborn Laboratories of Marine Sciences, New York Aquarium, Wildlife Conservation Society, Surf Avenue at West 8th Street, \\ Brooklyn, New York 11224, USA
}

${ }^{5}$ Present address: PO Box 99470, Mombasa 80107, Kenya

\begin{abstract}
We studied the effects of herbivory, fertilization and their interaction on algal succession on dead coral surfaces and the condition of live coral colonies. We used replicate open, closed, fertilized, and unfertilized cages in a 2-factor, 2-level design, sampled 7 times over a $49 \mathrm{~d}$ summer period at an offshore reef atoll lagoon in Belize. Herbivory negatively influenced algal biomass, whereas nutrients positively influenced wet but not dry or decalcified measures. Total and turf algal cover were positively influenced by nutrients and negatively by herbivory. Biomass was more strongly influenced by herbivory than fertilization, and the opposite was true for cover. Brown frondose algal cover was negatively influenced by both herbivory and nutrients, whereas red frondose algal cover was negatively affected by herbivory but unaffected by nutrients. There were more algal taxa and higher dominance in low compared to high herbivory treatments. In contrast to the relative dominance model (RDM), we found that turf algae did best under conditions of low herbivory and high nutrients, and also dominated high herbivory and low nutrient conditions, whereas frondose brown algae did best under low herbivory and low nutrient conditions, and appeared to be inhibited by high nutrients. Stony corals did sufficiently well in all conditions such that it was not possible to determine their optimal conditions, but elevated nutrients may provide resistance to end-of-summer bleaching by increasing the standing densities of algal symbionts. There were no detectable changes in symbiont community composition with all symbionts being members of Symbiodinium clade $A$. Coral mortality and low herbivory are most likely to be responsible for the high levels of brown frondose algae reported on these patch reefs.
\end{abstract}

KEY WORDS: Algae $\cdot$ Bleaching $\cdot$ Coral $\cdot$ Reef $\cdot$ Crustose coralline algae $\cdot$ Eutrophication $\cdot$ Frondose algae $\cdot$ Herbivory $\cdot$ Relative dominance model $\cdot$ Symbiodinium $\cdot$ Symbiosis

\section{INTRODUCTION}

The role of herbivory, nutrients, and their interaction in controlling the benthic ecology of coral reefs has been a focus of a number of recent ecological studies (Hatcher \& Larkum 1983, Littler et al. 1991, McCook
1996, 1999, McCook et al. 2001, Miller et al. 1999, Smith et al. 2001, Stimson et al. 2001, Thacker et al. 2001, Belliveau \& Paul 2002). Findings indicate the response can be complex and not always consistent between experimental methods, habitats, and regions. Nonetheless, one common model, the relative domi- 
nance model (RDM: Littler \& Littler 1984), has proved to be a simple and useful model for developing and testing hypotheses concerning the dual and interactive effects of nutrients and herbivory (see Fig. 1). The RDM predicts that the dominance of 4 major coral reef functional groups can be determined by levels of herbivory and nutrients. Corals are hypothesized to dominate under high grazing and low nutrients, turf algae dominate under low nutrients and low grazing, crustose coralline algae under high nutrients and high grazing, and frondose algae under low grazing and high nutrients (Fig. 1). This simple model, with 2 interacting factors and levels, is easily tested through experimentation.

In this paper, we present the results of a small-scale study to test the effects of these 2 factors (nutrients and herbivory) with 2 treatment levels (high and low) on algal succession on the surfaces of dead coral, as well as on the condition of live coral colonies in the same treatments. The experiments used cages located in the lagoon of a remote coral reef atoll in Belize (McClanahan et al. 2001). We were interested in testing the RDM hypothesis and increasing our understanding of the factors that have led to frondose macroalgal dominance in the patch reefs of this lagoon over the past 25 yr (McClanahan \& Muthiga 1998). A previous study using these cages was completed in the previous year and focused on 3 single factors: herbivory, nutrients (high phosphorus), and coral cover (McClanahan et al. 2002). This study found that all of these factors influenced algal ecology, but the design did not allow for testing of the possible interactions between 2 of the most important forces (herbivory and nutrients), and the results conflicted with the predictions of the RDM hypothesis. Consequently, in this study, we evaluate this interaction and experimentally test the RDM hypothesis in this patch reef habitat.

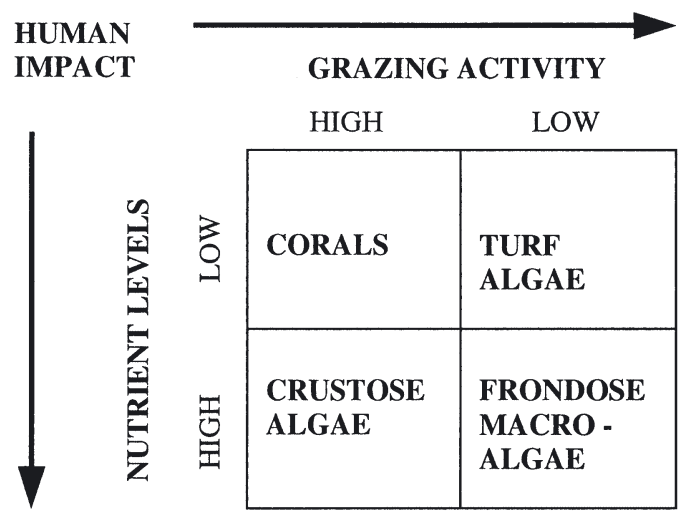

Fig. 1. A graphic depiction of the relative dominance model (RDM) showing expected benthic dominance under the 2 levels of nutrients and herbivory (adapted from Littler et al. 1991)

\section{MATERIALS AND METHODS}

Study site. A full description of the study site is presented in McClanahan et al. (2002). The most important aspects of the study site relevant to this study is that it is in a conservation area where fishing has been excluded since 1995 and is $45 \mathrm{~km}$ offshore from a country with a low human population density. A number of previous studies have described herbivory in this area and levels are moderate with Thalassia assays having $\sim 40 \%$ bite rates (McClanahan 1999, McClanahan et al. 2001). Nutrient concentrations in this area have been measured at various times and phosphates are stable at around 0.1 to $0.3 \mu \mathrm{M}$, whereas nitratenitrogen is more variable ranging from 0.1 to $1.0 \mu \mathrm{M}$ (McClanahan et al. 2002, P. Mumby \& T. McClanahan unpubl. data). The site is unlikely to be influenced greatly by human or urban waste and runoff, although possibly, on rare occasions, by mixing from hurricanes and runoff from large storms (Andrefouet et al. 2002). Cages were placed at $2 \mathrm{~m}$ depth in the lagoon on the windward side of a patch reef. Tidal range is small $(<0.5 \mathrm{~m})$, currents are low to moderate $\left(<1 \mathrm{~m} \mathrm{~s}^{-1}\right)$, and there were no waves or other physical disturbances, such as hurricanes, during the summer study period (May 7 to July 7,2001 ). The experiment was undertaken during the summer, when we would expect algal growth and its responses to fertilization and herbivory to be the fastest.

Experimental design. The experiment used 16 cages with 2 levels or types of herbivory (tops of cages open or closed) and 2 nutrient levels (fertilized or unfertilized). Each of the 4 treatments had 4 replications with a crossed design that allowed a test of the interaction between the 2 factors. The 16 cages (each $50 \mathrm{~cm}$ in length and width, and $20 \mathrm{~cm}$ in height) were constructed with $\mathrm{PVC}$ frames and $3 \mathrm{~cm}$ mesh caging material. The wide spacing of the mesh is expected to have little influence on light and water motion in the cages. Cages were tied to cement masonry blocks placed on the sides of the cages to keep them solidly on the reef bottom. Cages were placed no less than $1 \mathrm{~m}$ apart and perpendicular to the dominant southwest current, such that water from the cages would not influence each other. Cages were cleaned of algae and other settling organisms with wire brushes every other day. Closed-top treatments exclude large herbivorous fishes, but allow small fishes such as damselfishes and small parrotfishes to enter and graze (McClanahan et al. 2002). This is expected to simulate herbivory at 2 levels of fishing, 1 with and 1 without large herbivores. Open-top cages were grazed by large fishes at rates equivalent to previous studies (McClanahan et al. 2000, 2001).

In the fertilized cages, $1.5 \mathrm{~kg}$ Scott's slow-release fertilizer was spread evenly beneath the plates at the 
start of the experiment and again after $35 \mathrm{~d}$. The fertilizer was a mix of $66 \%$ high-P Osmocote and $34 \%$ high-N Osmocote fertilizer. The $\mathrm{P}$ fertilizer had a 10:50:0 N:P:K ratio, with $10 \%$ nitrogen as ammonium and $50 \%$ phosphorus as $\mathrm{P}_{2} 0_{5}$. The $\mathrm{N}$ fertilizer had a 23:0:0 N:P:K ratio with $11.5 \%$ as nitrate and $11.5 \%$ as ammonium. The $\mathrm{N}$ fertilizer also contained $0.5 \%$ sulfur (as sulfate) and 3.3\% calcium. The fertilizer cages, therefore, received a dose of $500 \mathrm{~g} \mathrm{P}_{2} \mathrm{O}_{5}, 215 \mathrm{~g}$ ammonium and $57.5 \mathrm{~g}$ nitrate at the start of the experiment. Scott's fertilizer company reports the longevity of this fertilizer at $31^{\circ} \mathrm{C}$ to be 1 to $4 \mathrm{mo}$, with the $\mathrm{N}$ fertilizer at the low end and the P fertilizer at the high end of these estimates. Scott's fertilizer company tests to ensure that the fertilizer does not contain toxic chemicals such as heavy metals.

To measure algal abundance and species composition, 8 dead Acropora palmata 'plates' were placed flat on the bottom of each cage. Seven were used for the weekly sampling of algal biomass and 1 was sampled at the end of the experiment for analysis of algal species composition. The plates were collected from the shallow reef flat on the windward side of the atoll rim. To ensure similar initial conditions and to make it possible to scrape algae from their surfaces, the plates were scrubbed with a wire brush and bumps were removed with a stone blade of a hacksaw. Despite the scrubbing, some crustose coralline algae remained and covered approximately $5 \%$ of the surface area. In each cage, 4 small live colonies of Porites astreoides $(<20 \mathrm{~cm}$ diameter) and $P$. furcata $(<15 \mathrm{~cm}$ long) were distributed haphazardly among the dead Acropora plates.

Measurements. Water samples were collected twice in each cage in acid-washed $100 \mathrm{ml}$ Nalgene bottles for measuring nitrate and soluble phosphate concentrations. The first sampling period was $1 \mathrm{wk}$ after the initiation of the experiment, and the second was $1 \mathrm{wk}$ before the end of the experiment. Sampling bottles were opened $1 \mathrm{~cm}$ above the coral plate surfaces and analyzed on the same day with a Hach Odyssey DR/2500 spectrophotometer at the Middle Key Field Station. Nitrate was determined by the cadmium reduction method and phosphate by the ascorbic acid method.

To determine whether the cages influenced the levels of herbivory and foraging of small fishes, observations on their abundance and feeding were made twice during the study period. We observed each cage for 3 min, taking care not to disturb the area by stirring sediments or abrupt movements. Within each cage, the number of damselfish, parrotfish, and wrasses observed during $1 \mathrm{~min}$ were counted. After counting, 1 fish was selected at random and observed, and the number of bites that it took was recorded over $1 \mathrm{~min}$. Fish observations were made at $28 \mathrm{~d}$ and again at the conclusion of the study, such that each treatment was observed for 32 min over the study period.

Each week, 1 previously unsampled plate from each cage was collected to measure algal biomass accumulation, such that 4 replicates of the 4 treatments were sampled. Algae from a $10 \times 10 \mathrm{~cm}$ area were removed from each plate with a razor blade. The wet biomass collected was then placed in pre-weighed tinfoil squares and re-weighed (wet biomass). The tinfoil squares were then oven-dried for 45 to $60 \mathrm{~min}$ at 90 to $120^{\circ} \mathrm{C}$ and weighed again (dry biomass). Samples were then placed in hydrochloric acid $(0.5 \mathrm{M} \mathrm{HCl})$ overnight and then re-weighed after being filtered and dried as above (decalcified biomass).

Estimates of the biomass of the individual algae species were made at the end of the experiment by scrapping a $20 \times 20 \mathrm{~cm}$ area from a previously unsampled plate. Samples were sealed in plastic bags, and stored in a $4 \%$ formaldehyde solution. Algae were identified to the lowest taxon possible in the laboratory following the nomenclature of Littler \& Littler (2000) and were classified into 5 functional groups: turf, frondose, geniculated coralline, crustose coralline, and crustose non-coralline algae. Frondose algae were taxa with an erect, gelatinous, stiff, or bushy thallus; turf algae had a fine, filamentous, hairy, fuzzy or turf-forming thallus; geniculated corallines were erect with articulated thalli; crustose-non corallines were all encrusting types, mainly the encrusting stage of Lobophora variegata; and crustose corallines were taxa such as Hydrolithon that form creeping crust-like thalli, as described by Littler \& Littler (2000). For each plate, the species were separated under a binocular microscope and each taxon weighed to the nearest milligram.

During the weekly sampling, the relative cover of algae was estimated on the plates. Percent cover estimates for algae are rapid, non-destructive methods to assess community dominance. Macroscopic algae were distinguished and classified. No green calcareous algae (i.e. Halimeda) were observed during the weekly visual surveys. Relative cover was measured on 5 randomly selected plates per cage weekly (until fewer than 5 unscraped plates remained) in the field. Cover percentages were obtained by haphazardly dropping the point of a pencil on each plate 20 times. The functional group of algae underneath the pencil point was then recorded.

The condition and color of the corals in the cage were carefully examined and recorded at the beginning of the experiment. Porites astreoides normally has a mustard-yellow color, while the $P$. furcata we studied was dark yellow to brown. During each sampling period, an estimate of the percentage of coral cover that was normal, pale, or darkened in each cage was recorded for each species. Pale corals lost color, and 
some white skeleton could be seen through the tissue. Darkened corals often turned dark green. We also estimated the percentages of coral surface that were living and dead.

Branches or plugs ( 1 to $2 \mathrm{~cm}^{2}$ ) of coral were removed from colonies in each treatment to sample the symbiotic algae present. We (1) measured symbiont densities (numbers of cells per unit surface area of coral tissue) at the start of the experiment and again after $28 \mathrm{~d}_{\text {; }}$ and (2) extracted, purified, and analyzed symbiont DNA to identify the dominant type(s) of Symbiodinium present at the start of the experiment and after $49 \mathrm{~d}$. Coral samples were collected by divers in labeled ziplock bags, and either processed immediately, following procedures outlined in Baker et al. 1997, or stored for 4 to 6 mo at room temperature in saline DMSO solution. Symbionts were identified using restriction fragment length polymorphisms (RFLPs) in amplified large subunit ribosomal genes using techniques described by Baker et al. (1997).

Statistical analyses. Data were tested for normality and equal variances before undertaking statistical tests. If data were not normally distributed, then log and arcsin transformation were completed, tested again for normality, and the best-fit transformations used in the statistical tests. Comparisons of the algal cover and biomass estimates were tested for overall statistical significance by MANOVA and followed by univariate analyses. Not all cover data were normally distributed, so we also performed a Wilcoxon nonparametric univariate analysis on the data that were not normally distributed. The MANOVA of the algal biomass was based on the log-transformed variables of wet, dry, and decalcified weights with all factors of cage, nutrients, and time, as well as their interactions tested. When MANOVAs were undertaken, covariance was tested for sphericity by the Mauchly criterion and for both cover and biomass data found to be nonspherical, and therefore the Huyn-Feldt adjusted degrees of freedom, exact $F$, and probabilities are presented. Cover of the plates, fish presence and feeding, and coral coloration were analyzed by 3-way full factorial univariate ANOVAs when transformed data were normally distributed. In some cases, transformations were unsuccessful in normalizing or achieving equal variances. The Welch's ANOVA was used if equal variance was not achieved, and nonparametric Wilcoxon tests in cases where normality was not achieved. JMP statistical package was used for all statistical testing (Sall et al. 2001).

Two types of multivariate analyses were performed: a principal component analysis (PCA) to characterize the main trends of variation in the abundance of algal species with respect to the treatments, and a detrended correspondence analysis for algal groups as described by Legendre \& Legendre (1998). To characterize the main trends of variation of abundance of algal species with respect to the treatments, we used a PCA on untransformed data (Legendre \& Legendre 1998). We used a linear indirect gradient analysis (PCA) because the species responded roughly linearly to gradients (gradient length $<4$ SD) (ter Braak \& Smilauer 1998). Scaling was focused on inter-species correlations and the species scores divided by the SD. To characterize the main trends of variation of abundance of algal groups with respect to the treatments, we used a DCA, since algal groups showed a strong unimodal response (gradient length $>4 \mathrm{SD}$ ). We chose the detrended form of the correspondence analysis to counteract the arch effect in the ordination diagram.

\section{RESULTS}

\section{Nutrient concentrations}

Fertilization was successful in increasing mean phosphate levels from 0.16 to $0.48 \mu \mathrm{M}$, but had no effect on nitrate levels (Table 1). Phosphate levels were also higher in the final than the initial levels, such that

Table 1. Concentrations $(\mu \mathrm{M})$ of phosphates and nitrates in control and fertilized cages $1 \mathrm{wk}$ after the initiation of the experiment and $1 \mathrm{wk}$ before the termination of the experiment. For each nutrient, 2-factor interactive ANOVA statistics are presented. ns $=$ not significant

\begin{tabular}{|c|c|c|c|c|}
\hline \multirow[b]{2}{*}{ Phosphate, $\mathrm{PO}_{4}-\mathrm{P}$} & \multicolumn{2}{|c|}{ Control } & \multicolumn{2}{|c|}{ Fertilized } \\
\hline & Mean & $\mathrm{SD}$ & Mean & $\mathrm{SD}$ \\
\hline Initial & 0.11 & 0.09 & 0.21 & 0.09 \\
\hline Final & 0.21 & 0.15 & 0.76 & 0.38 \\
\hline Total & 0.16 & 0.12 & 0.48 & 0.39 \\
\hline ANOVA & $\mathrm{df}$ & $F$ & \multicolumn{2}{|c|}{ p-value } \\
\hline Time 1 & 9.46 & 0.01 & \\
\hline Fertilization & 1 & 9.46 & \multirow{2}{*}{\multicolumn{2}{|c|}{$\begin{array}{l}0.01 \\
0.05\end{array}$}} \\
\hline Interaction & 1 & 4.55 & & \\
\hline Within & 12 & & & \\
\hline Total & 15 & & & \\
\hline Nitrate, $\mathrm{NO}_{3}-\mathrm{N}$ & Mean & $\mathrm{SD}$ & Mean & $\mathrm{SD}$ \\
\hline Initial & 0.20 & 0.08 & 0.44 & 0.20 \\
\hline Final & 2.94 & 1.72 & 2.10 & 1.50 \\
\hline Total & 1.57 & 1.85 & 1.27 & 1.33 \\
\hline ANOVA & $\mathrm{df}$ & $F$ & \multicolumn{2}{|c|}{ p-value } \\
\hline Time 1 & 14.75 & 0.002 & \multirow{2}{*}{\multicolumn{2}{|c|}{$\mathrm{ns}$}} \\
\hline Fertilization & 1 & 0.28 & & \\
\hline Interaction & 1 & 0.90 & \multicolumn{2}{|c|}{$\mathrm{ns}$} \\
\hline Within & 12 & & & \\
\hline Total & 15 & & & \\
\hline
\end{tabular}


Table 2. Statistical results for fish counts, and individual and per cage bite rates based on 2 sampling periods to determine the effect of the cages on small fish able to enter and occupy the cages. Two statistical tests were performed based on whether the data were normally distributed and had equal variances. Significant $p$-values $\leq 0.05$ are in bold

\begin{tabular}{|c|c|c|c|c|c|c|c|c|}
\hline \multirow[t]{2}{*}{ Factor } & \multicolumn{2}{|c|}{ Wrasses } & \multicolumn{2}{|c|}{ Parrotfish } & \multicolumn{2}{|c|}{ Damselfish } & \multicolumn{2}{|c|}{ Total fish } \\
\hline & $F / \chi^{2}$ & $\mathrm{p}$ & $F / \chi^{2}$ & $\mathrm{p}$ & $F / \chi^{2}$ & $\mathrm{p}$ & $F / \chi^{2}$ & $\mathrm{p}$ \\
\hline \multicolumn{9}{|c|}{ Number of individuals } \\
\hline Time & 0.6 & 0.43 & 0.70 & 0.40 & 0.59 & $0.45^{*}$ & 0.00 & $0.83^{*}$ \\
\hline Herbivory & 1.6 & $0.23^{*}$ & 11.60 & 0.001 & 0.44 & 0.51 & 5.30 & $0.02^{*}$ \\
\hline Nutrients & 0.0 & $0.60^{*}$ & 1.00 & 0.30 & 3.73 & 0.05 & 0.10 & 0.76 \\
\hline \multicolumn{9}{|c|}{ Bites per individual per minute } \\
\hline Time & 1 & 0.32 & 3.30 & $0.09^{*}$ & 2.79 & $0.12^{*}$ & 1.90 & $0.17^{*}$ \\
\hline Herbivory & 1 & 0.32 & 4.70 & 0.03 & 0.26 & 0.61 & 2.20 & $0.14^{*}$ \\
\hline Nutrients & 1 & 0.32 & 1.10 & 0.30 & 5.69 & 0.02 & 0.60 & $0.45^{*}$ \\
\hline \multicolumn{9}{|c|}{ Bite per cage per minute } \\
\hline Time & 1 & 0.32 & 1.80 & $0.19^{*}$ & 3.80 & $0.07^{*}$ & 1.40 & $0.24^{*}$ \\
\hline Herbivory & 1 & 0.32 & 4.80 & 0.03 & 1.10 & $0.31^{*}$ & 3.20 & 0.007 \\
\hline Nutrients & 1 & 0.32 & 1.00 & $0.33^{*}$ & 5.70 & 0.02 & 1.10 & $0.29^{*}$ \\
\hline${ }^{*}$ Welch's AN & & & & & & & & \\
\hline
\end{tabular}

the treatment, time, and their interaction were all statistically significant. Nitrate levels and variation were also considerably higher in the final compared to the initial sampling, such that time was significant, but not the treatment or the interaction.

\section{Fish occupation and foraging in cages}

Wrasse abundance and bite rates were not influenced by the treatments at our level of sampling (Table 2). Small parrotfish (mostly Scarus iserti and juveniles of some other species) were more abundant and fed more frequently in the open than closed cages, and this increased the total density and bite rates of fish in the open cages. Damselfish abundance and bite rates were elevated in the fertilized cages, but this did not increase the total bite rate in the fertilized cages.

\section{Algal abundance and species composition}

Wet, dry and decalcified algal biomass increased in all treatments for the first $21 \mathrm{~d}$ before either stabilizing or decreasing until the end of the experiment at $49 \mathrm{~d}$ (Fig. 2, Table 3). The adjusted MANOVA indicated that all single-factors of time, nutrients, and herbivory, but none of the interactions, were statistically significant. Fertilization increased the wet weight of algal biomass $(F=4.2, \mathrm{p}<0.042)$ but did not influence the other measures of biomass. The fertilization effect was about $1 / 3$ less strong than the herbivory effect on biomass (Table 3).

The MANOVA test of the algal cover data indicated that all factors of time (adjusted $F=45.8$ ), herbivory
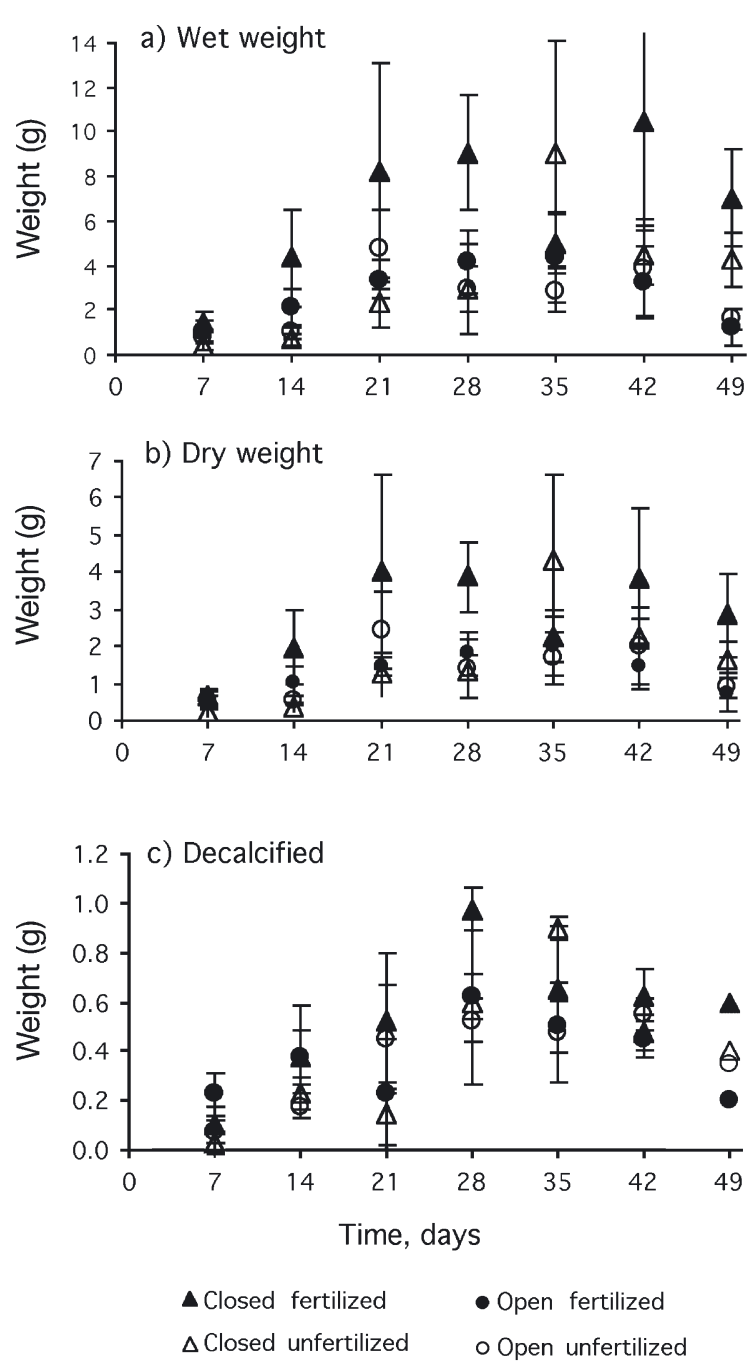

Fig. 2. Changes in (a) wet, (b) dry, and (c) decalcified algal biomass in the 4 treatments $( \pm \mathrm{SE})$ 
Table 3. MANOVA statistics with sphericity test and HuynFeldt corrections for the algal biomass based on the 3 measures of wet, dry and decalcified weight. Num df: numerical df. Significant $p$-values $\leq 0.05$ are in bold

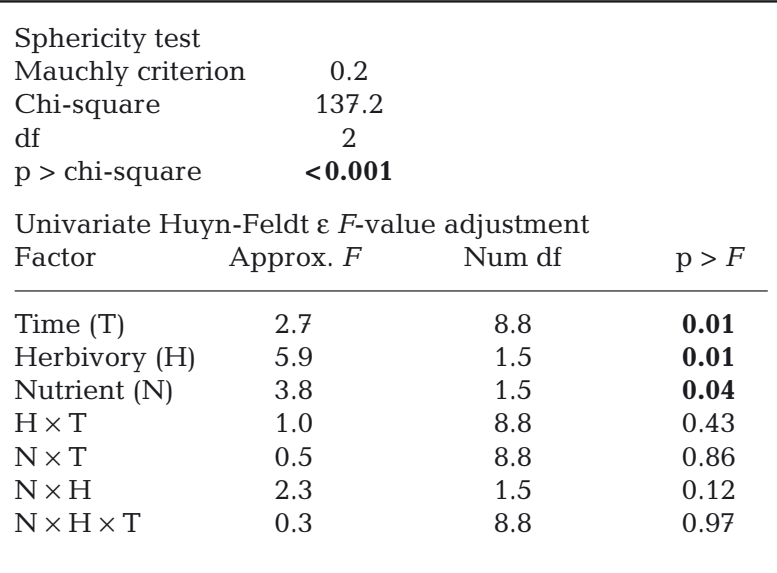

$(F=49.2)$, and fertilization $(F=47.0)$ were of approximately equal strength, and all bivariate interactions $(F>3.4)$ were statistically significant $(\mathrm{p}<0.01)$. Total, turf, brown frondose, and coralline algae cover were all influenced by time, with total algal cover increasing to $70 \%$ of the plate at $42 \mathrm{~d}$. However, time was not significant for red frondose algae (Fig. 3, Table 4). The herbivory treatment influenced all categories of cover except for crustose corallines, which declined with time in all treatments, but was relatively more abundant in the open-fertilized cages due to the lack of other taxa in this treatment (Fig. 4, Table 4). Fertilization positively influenced the total and turf algae cover. Fertilization had a stronger effect than herbivory for turf algae. Red and brown frondose algae increased in the closed cages, and red in both the fertilized and unfertilized cages, but brown was negatively affected by fertilization.

Examination of the taxa at the end of the experiment in each treatment indicated closed cages had more taxa, with 23 compared to 14 in open cages, with no effect due
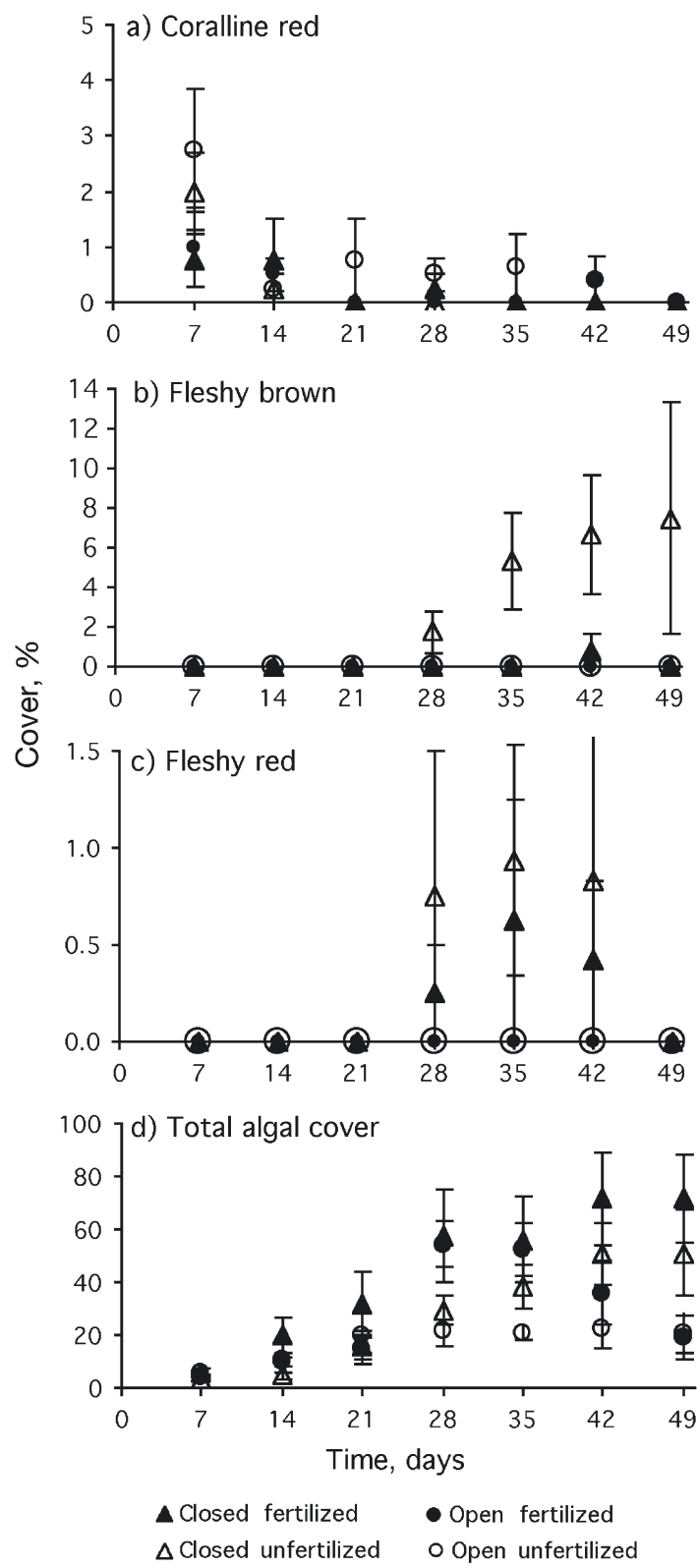

Fig. 3. Changes in percent algal cover on the experimental plates in the 4 treatments $( \pm \mathrm{SE})$

Table 4. Three interactive ANOVA statistics of the percentage cover estimates based on 7 sampling periods. Total and turf algae data were normally distributed and tested by univariate multifactor ANOVA; however, the other groups were not transformable to normality and tested with the Wilcoxon test. Significant $p$-values $\leq 0.05$ are in bold

\begin{tabular}{|c|c|c|c|c|c|c|c|c|c|c|c|}
\hline \multirow[t]{2}{*}{ Factor } & \multirow[t]{2}{*}{$\mathrm{df}$} & \multicolumn{2}{|c|}{ Total algae } & \multicolumn{2}{|c|}{ Turf algae } & \multicolumn{2}{|c|}{ Brown frondose } & \multicolumn{2}{|c|}{ Red frondose } & \multicolumn{2}{|c|}{ Crustose coralline } \\
\hline & & $F$ & $\mathrm{p}$ & $F$ & $\mathrm{p}$ & $\chi^{2}$ & $\mathrm{p}$ & $\chi^{2}$ & $\mathrm{p}$ & $\chi^{2}$ & $\mathrm{p}$ \\
\hline Time $(\mathrm{T})$ & 6 & 49.4 & $<0.0001$ & 58.6 & $<0.0001$ & 33.7 & $<0.0001$ & 11.7 & 0.07 & 53.8 & $<0.0001$ \\
\hline Herbivory (H) & 1 & 15.8 & $<0.0001$ & 11.8 & $<0.001$ & 26.2 & $<0.0001$ & 8.1 & $<0.0001$ & 2.1 & 0.15 \\
\hline Nutrients (N) & 1 & 21.0 & $<0.0001$ & 33.3 & $<0.0001$ & 22.2 & $<0.0001$ & 0.5 & 0.48 & 3.2 & 0.07 \\
\hline $\mathrm{T} \times \mathrm{H}$ & 6 & 2.0 & 0.07 & 1.7 & 0.11 & & & & & & \\
\hline $\mathrm{N} \times \mathrm{T}$ & 6 & 1.6 & 0.14 & 1.0 & 0.42 & & & & & & \\
\hline $\mathrm{H} \times \mathrm{N}$ & 1 & 0.7 & 0.39 & 1.4 & 0.23 & & & & & & \\
\hline $\mathrm{H} \times \mathrm{N} \times \mathrm{T}$ & 6 & 2.6 & 0.02 & 2.0 & 0.06 & & & & & & \\
\hline
\end{tabular}



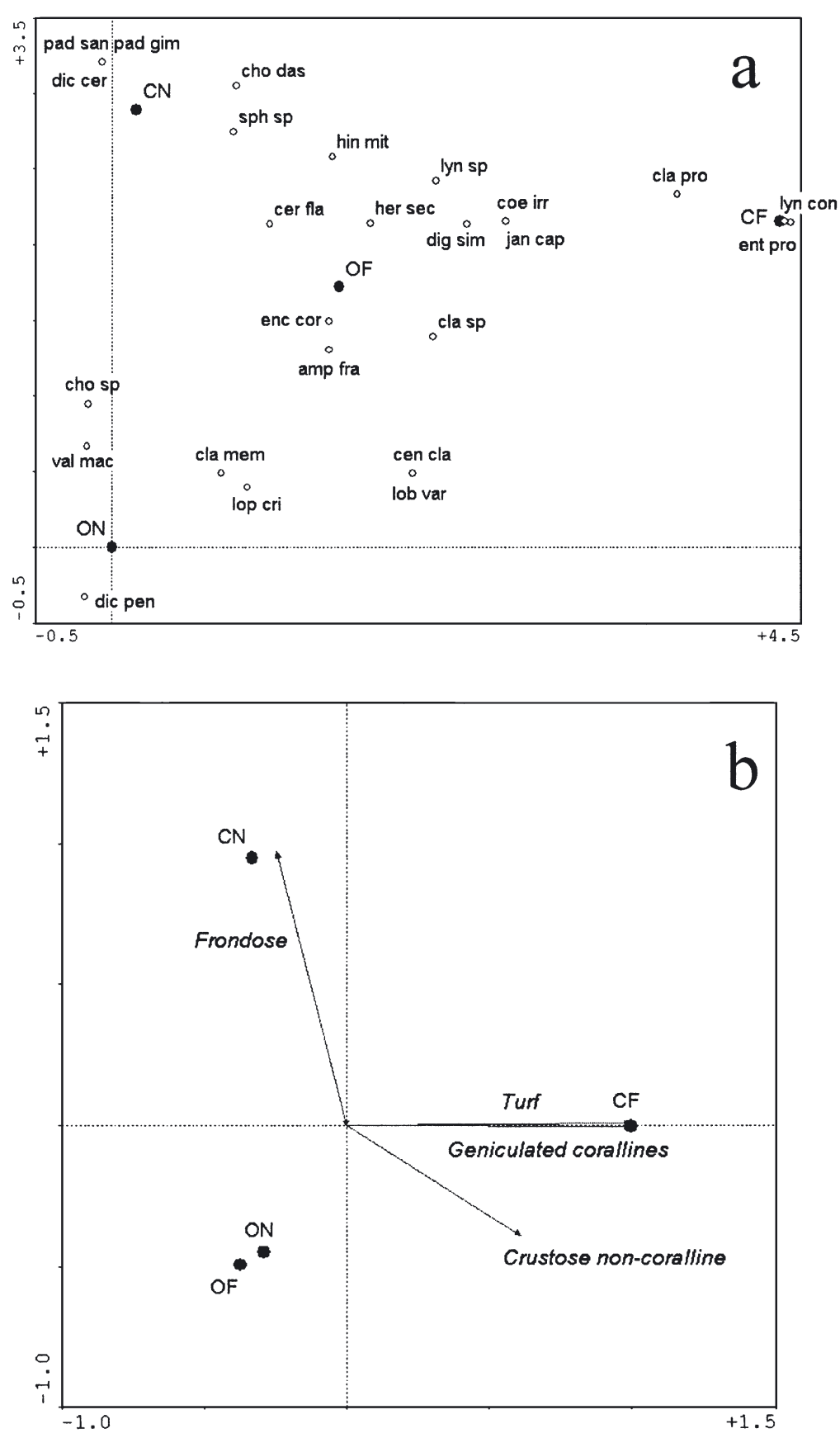

Fig. 4. Multivariate analyses of (a) algal species and (b) algal functional groups in the 4 treatments. Treatments: ON: open non-fertilized; OF: open fertilized; $\mathrm{CN}$ : closed non-fertilized; CF: closed fertilized. Species: amp fra: Amphiroa fragilissima; cer cla: Centroceras clavulatum; cer fla: Ceramium flaccidum; cho das: Chondria dasyphylla; cho sp: Chondria sp.; cla mem: Cladophoropsis membranacea; cla pro: Cladophora prolifera; cla sp: Cladophora sp.; coe irr: Coelothrix irregularis; dic cer: Dictyota cervicornis; dic pen: Dichotrix pennicillata; dig sim: Digenea simplex; enc cor: encrusting corallines; ent pro: Enteromorpha prolifera; her sec: Herposiphonia secunda; hin mit: Hincksia mitchelliae; jan cap: Jania capillacea; lob var: Lobophora variegata; lop cri: Lophopsiphonia cristata; lyn con: Lyngbya Confervoides; lyn sp: Lyngbya sp.; pad gim: Padina gymnospora; pad san: Padina sanctae-crucis; sph sp: Sphacelaria sp.; val mac: Valonia macrophysa to the fertilization treatment (Table 5). Closed cages also had greater algal biomass and lower diversity than open cages. The most dominant species, the blue-green Lyngbya confervoides, was found in the closed and fertilized cages along with other turf algae, such as the filamentous green turf algae Entermorpha prolifera and Cladophora prolifera as well as the red turf alga Digenia simplex (Fig. 4). The brown frondose algae Padina sanctaecrucis and Dictyota cervicornis dominated the closed-unfertilized cages, with lesser abundance of other frondose red and greens such as Chondria dasyphylla, Champia parvula, and Valonia macrophysa. The open cages had low abundance of most species. The open-fertilized cages had the highest relative abundance of crustose corallines, but the absolute value did not differ from the other treatments, and the second most abundant algae was the brown filamentous turf algae Hincksia mitchelliae. The most abundant algae in open-unfertilized cages were the blue-green Dichothrix penicillata, with lower abundance of the frondose Valonia macrophysa and the filamentous red Digenia simplex.

The PCA analysis of the abundance based on functional groups indicates that the closed-fertilized treatment was dominated by small, fast-growing species (turf algae) (Fig. 4, Table 5). The open-fertilized treatment was dominated by turf algae, although their biomass was low compared to the closed-fertilized treatment. The closedunfertilized treatment was dominated by frondose algae, turf algae being the second most important group. The open-unfertilized treatment was dominated by turf algae.

\section{Coral survival and coloration}

There was no mortality in any treatment, but there were notable changes in the coloration of the corals for both studied species. Within 28 d, nearly all Porites astreoides and $P$. furcata assumed a dark green coloration in the fertilized cages regardless of the level of herbivory (Fig. 5). Time, fertilization, and their interaction were highly significant for both species, the effect being somewhat stronger for $P$. astreoides than for P. furcata (Table 6). In the unfertilized treatments, slight paling had occurred in both species by $28 \mathrm{~d}$, with the effect also being stronger for $P$. astreoides than 
for $P$. furcata. The effect of time, fertilization, and their interaction were significant for both species, but for $P$. furcata the herbivory and Herbivory $\times$ Nutrient interaction were also marginally significant ( $\mathrm{p}<0.054)$, with open cages having slightly more paling than closed cages. Symbiont densities doubled in the fertilized cages, but remained unchanged in unfertilized cages after $28 \mathrm{~d}$ (Table 7). There were no detectable changes in Symbiodinium community structure after $49 \mathrm{~d}$, with all colonies containing indistinguishable members of Symbiodinium clade $A$ (Table 7).

a) Darkened Porites asteroides
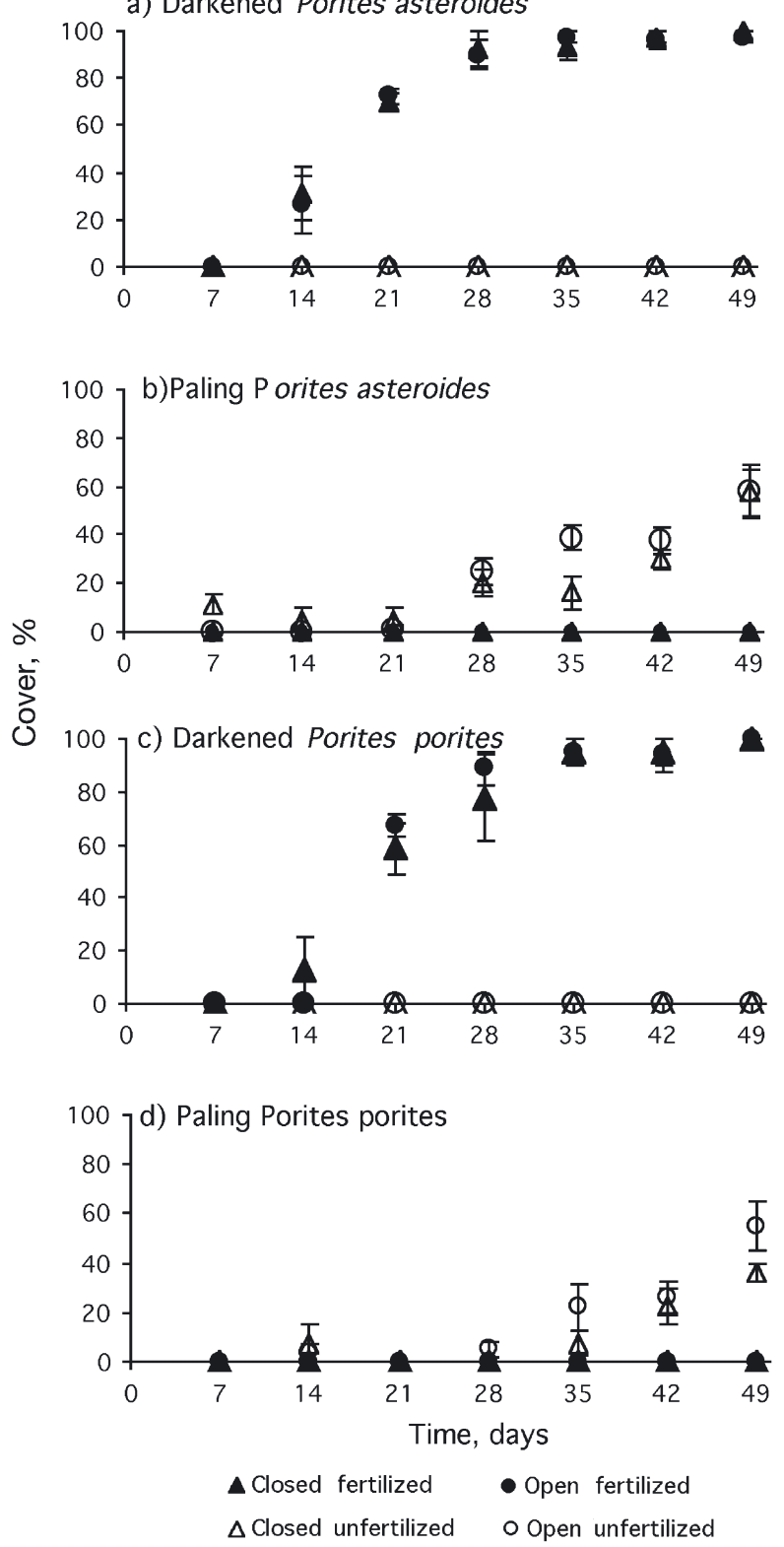

Fig. 5. Changes in coral coloration (determined visually) in the 4 experimental treatments $( \pm \mathrm{SE})$

\section{DISCUSSION}

This study examined the interaction between fertilization and herbivory in a remotely located marine protected area. The intention was to study these factors and their interaction where influences external to the experiment, such as fishing, terrestrial runoff, and human waste, would be minimal and unlikely to influence the experimental results. The experiment was also located in a reef lagoon where physical factors, such as waves, currents, and associated movement of sediments, were not strong and unlikely to disturb the cages or the experimental plates. Fishing has been excluded from this reef for approximately $6 \mathrm{yr}$ prior to this experiment, but herbivory in these patch reefs is only moderately high based on counts of fish and herbivory assays (McClanahan 1999, McClanahan et al. 2000, 2001). Herbivory may not be representative of 'pristine' or unfished conditions, but was sufficient to control the algae and biomass in the experiments, and probably high relative to less remote Caribbean lagoonal patch reefs without protection from fishing. The experimental design was successful in eliminating the larger herbivores in the closed-top cages, but all of the cages were occupied by smaller herbivores, namely small parrotfish and damselfish. There were differences in parrotfish and damselfish, with parrotfish preferring the open-top and damselfish the fertilized cages. The closed-top cages were successful in eliminating the larger herbivores, namely surgeonfish, parrotfish, and chubs, and therefore reflected the conditions on reefs where heavy fishing has eliminated the large, but not all small herbivores. Small herbivores and their grazing rates were also somewhat elevated in the open top cages, such that we can be certain the caging did reduce total grazing rates. The one factor that may have confounded the assumed experimental effect was the higher bite rates of damselfish in the fertilized cages, but the overall bite rates were not different for treatments.

Nutrient concentrations in the unfertilized cages indicate stable and average levels of phosphates for coral reefs, but highly variable levels for nitrates. A summary of nutrient concentrations from 1000 reefs worldwide found mean phosphate concentrations of $0.13 \pm 0.08(\mu \mathrm{M}, \mathrm{SD})$, which are similar to our average of $0.16 \pm 0.12$ for our control cages (Kleypas et al. 1999). Mean nitrate concentrations for coral reefs are reported to be $0.25 \pm 0.28 \mu \mathrm{M}$, which is similar to our initial measurement of $0.20 \pm 0.08$, but considerably lower than our final measurement. There may have been a periodic build-up of nitrate during the final sampling, when wind and flushing were low and nitrogen-fixation high. Nitrates in coral reefs are generally quite variable in space and time, and our measure- 
Table 5. Algal species and their functional group in each of the 4 experimental treatments, total number of taxa, wet weight and diversity. Data are $\mathrm{mg}$ wet wt (mean $\pm \mathrm{SEM}$ ) of algae per $400 \mathrm{~cm}^{2}$ for each recorded species (units; mean, SE)

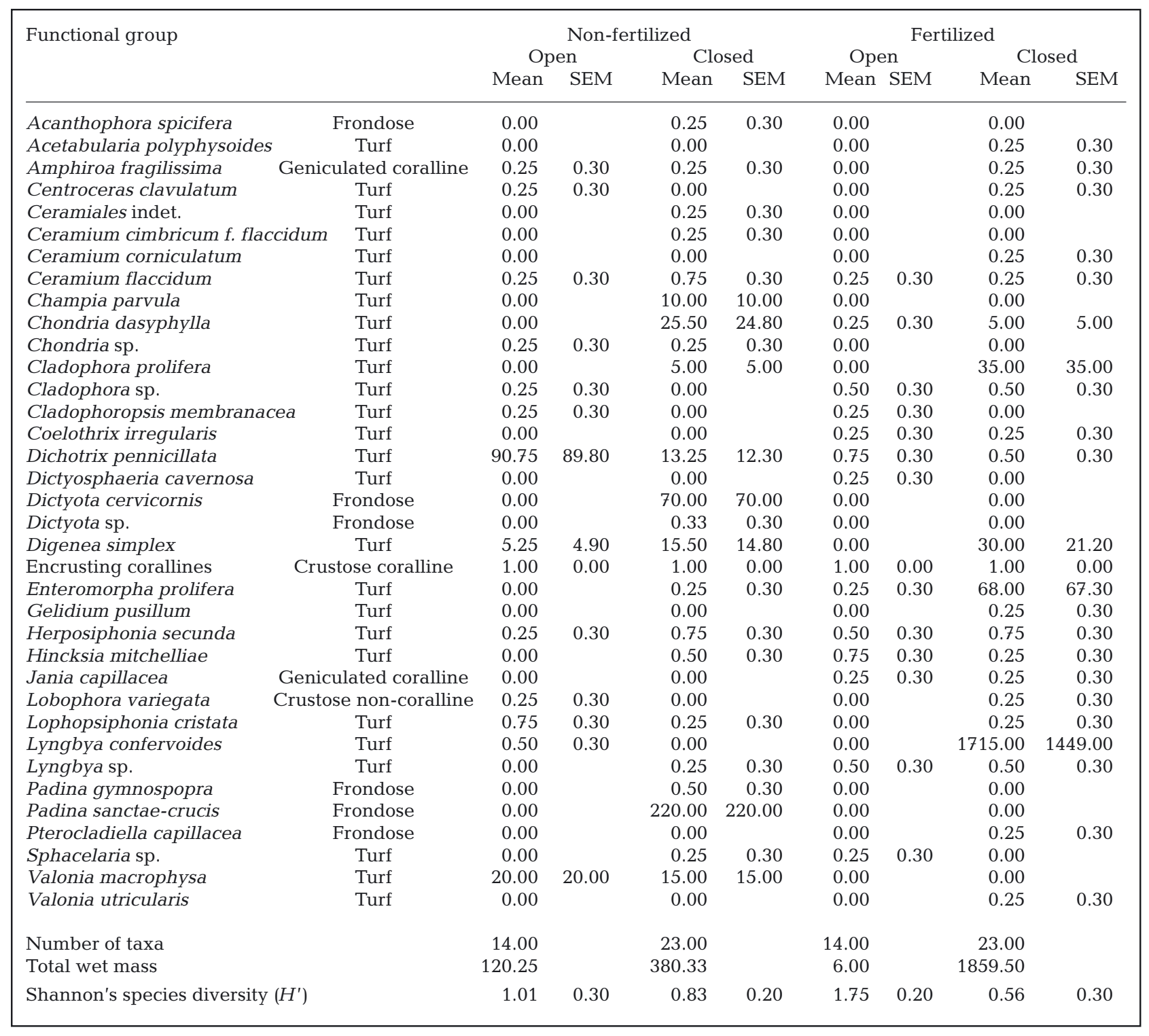

Table 6. Three-factor interactive ANOVA statistics of the coral coloration based on 7 sampling periods. Significant $p$-values $\leq 0.05$ are in bold

\begin{tabular}{|c|c|c|c|c|c|c|c|c|c|}
\hline \multirow[t]{3}{*}{ Factors } & \multirow[t]{3}{*}{$\mathrm{df}$} & \multicolumn{4}{|c|}{ Paling } & \multicolumn{4}{|c|}{ Darkened } \\
\hline & & \multicolumn{2}{|c|}{ Porites furcata } & \multicolumn{2}{|c|}{ Porites asteroides } & \multicolumn{2}{|c|}{ Porites furcata } & \multicolumn{2}{|c|}{ Porites asteroides } \\
\hline & & $F$ & $\mathrm{p}$ & $F$ & $\mathrm{p}$ & F & $\mathrm{p}$ & $F$ & $\mathrm{p}$ \\
\hline Time (T) & 6 & 20.20 & $<0.001$ & 25.70 & $<0.001$ & 73.30 & $<0.001$ & 92.50 & $<0.001$ \\
\hline Herbivory $(\mathrm{H})$ & 1 & 3.80 & 0.05 & 0.04 & 0.84 & 0.10 & 0.82 & 0.05 & 0.82 \\
\hline Nutrients (N) & 1 & 88.50 & $<0.001$ & 216.80 & $<0.001$ & 1119.0 & $<0.001$ & 1995.40 & $<0.001$ \\
\hline $\mathrm{T} \times \mathrm{H}$ & 6 & 1.20 & 0.29 & 1.00 & 0.43 & 0.60 & 0.74 & 0.10 & 0.99 \\
\hline $\mathrm{N} \times \mathrm{T}$ & 6 & 20.20 & $<0.001$ & 25.70 & $<0.001$ & 73.30 & $<0.001$ & 92.50 & $<0.001$ \\
\hline $\mathrm{H} \times \mathrm{N}$ & 1 & 3.80 & 0.05 & 0.04 & 0.84 & 0.10 & 0.814 & 0.10 & 0.82 \\
\hline $\mathrm{H} \times \mathrm{N} \times \mathrm{T}$ & 6 & 1.20 & 0.29 & 1.00 & 0.43 & 0.60 & 0.735 & 0.10 & 0.99 \\
\hline
\end{tabular}


Table 7. Effect of different predation and nutrient regimes on the density and identity of algal symbionts in experimental coral colonies and a single-factor ANOVA test of significance

\begin{tabular}{|c|c|c|c|c|c|c|c|}
\hline & $\begin{array}{c}\text { Symbiont identity } \\
\text { (no. of samples } \\
\text { successfully identified) }\end{array}$ & $\begin{array}{c}\text { Mean } \\
\left(\times 10^{6}{\left.\text { cells } \mathrm{cm}^{-2}\right)}^{-}\right.\end{array}$ & SEM & ANOVA & df & $F$ & p-value \\
\hline \multicolumn{8}{|l|}{ Porites astreoides } \\
\hline Initial: All treatments $(\mathrm{n}=64)$ & Symbiodinium A (64) & 1.17 & 0.13 & & & & \\
\hline Final: Control $(\mathrm{n}=16)$ & Symbiodinium A (16) & 1.02 & 0.14 & & & & \\
\hline Final: Caged $(n=16)$ & Symbiodinium A (16) & 1.28 & 0.12 & Caging & 1 & 0.18 & 0.676 \\
\hline Final: Fertilized $(\mathrm{n}=16)$ & Symbiodinium A (16) & 2.49 & 0.37 & Fertilization & 1 & 22.89 & 0.001 \\
\hline Final: Caged + Fertilized $(n=16)$ & Symbiodinium A (16) & 2.46 & 0.39 & Interaction & 1 & 0.29 & 0.595 \\
\hline \multicolumn{8}{|l|}{ Porites furcata } \\
\hline Initial: All treatments $(\mathrm{n}=64)$ & Symbiodinium A (64) & 0.93 & 0.08 & & & & \\
\hline Final: Control $(\mathrm{n}=16)$ & Symbiodinium A (16) & 0.83 & 0.10 & & & & \\
\hline Final: Caged $(\mathrm{n}=16)$ & Symbiodinium A (16) & 0.78 & 0.06 & Caging & 1 & 1.46 & 0.231 \\
\hline Final: Fertilized $(\mathrm{n}=16)$ & Symbiodinium A (16) & 1.59 & 0.19 & Fertilization & 1 & 35.81 & 0.001 \\
\hline Final: Caged + Fertilized $(n=16)$ & Symbiodinium A (16) & 2.05 & 0.27 & Interaction & 1 & 2.22 & 0.142 \\
\hline
\end{tabular}

ments are no exception. Fertilization had its greatest effect on phosphate concentrations, tripling mean concentrations. Despite the addition of nitrogen fertilizer we could not detect any influence on the concentrations of nitrates. Nearly $80 \%$ of the nitrogen in the fertilizer was, however, in the form of ammonium, and this may explain the inability to detect a nitrate effect. It is likely that ammonium was elevated, resulting in increased nitrogen available to the experimental algae, but our focus on the more easily measured nitrate may have resulted in an inability to measure this supplementary source.

Both herbivory and nutrients influenced the various measures of algae community. However, there were differences based on the measures used to describe the effect. For example, herbivory was a stronger factor than fertilization for biomass compared to cover. The majority of 2-factor interactive experimental studies have found that herbivory is a stronger factor than nutrients on algal biomass (Miller et al. 1999, Thacker et al. 2001, Belliveau \& Paul 2002) although the effect was indistinguishable in a Hawaiian study (Smith et al. 2001). Total algal cover was equally affected by herbivory and fertilization, but the response was variable for the algal functional groups, and there were clear differences in the species and functional group composition in the treatments based on their weights. There may also have been differences in the calcification and chemistry of the algae under these different treatments, mediated by differential nutrient uptake, calcification rates, survival, and/or growth of the species.

There are several differences between our findings and the predictions of the RDM. A notable difference is the dominance of turf algae under high nutrients and grazing, whereas by RDM, crustose corallines are predicted to dominate in these conditions. In our study, although the relative importance of crustose corallines is high, this is largely due to the elimination of other functional groups on the plates over time, rather than a cover increase for this group. Although high herbivory appears critical to the success of crustose corallines (Steneck 1983, 1997), there is a lack of consensus among field studies on the relationship between nutrients and crustose coralline success. For example, 2 studies have found that elevated phosphorus decreased the abundance of crustose corallines (Bjork et al. 1995, Belliveau \& Paul 2002). In contrast, a similar 5 mo duration study found that crustose corallines dominated on fertilized plates (Smith et al. 2001). It may take longer than 2 mo to see the full treatment effect on this slow-growing functional group (Dethier \& Steneck 2001).

There was a notable difference between our findings and the RDM predictions for frondose algae, which, as predicted, survived well under low grazing, but, contrary to predictions, survived poorly with fertilization. Filamentous turf algae dominated the fertilization-low grazing, fertilization-high grazing, and unfertilizedhigh grazing treatments, although with a slightly different mix of filamentous taxa and biomass between treatments. This finding is not unique, as the inhibition of frondose algae in the presence of high nutrients has been observed in other experimental studies in the Caribbean (Miller et al. 1999, McClanahan et al. 2002).

Three potential explanations for the lack of brown frondose algae in the high nutrient-low herbivory treatment are: (1) turf algae competitively excluded frondose algae under high nutrient conditions; (2) high nutrient concentrations inhibited frondose taxa; and (3) small herbivorous damselfish in the fertilized cages fed preferentially on frondose over filamentous turf algae because the high nutrient concentration in- 
creased their nutrition and palatability (McGlathery 1995). Our study did indicate that damselfish feed more frequently in the fertilized cages, and this could be the explanation, although total bite rates did not differ for these treatments. This explanation seems less likely considering that frondose algae is abundant on these reefs with numerous small herbivorous fish (McClanahan et al. 2001), and they are more aggressive in defending turf than frondose-dominated territories (McClanahan et al. 2000). Perhaps this condition and feeding behavior would change if the frondose algae were fertilized. The second explanation is also equivocal in view of the reported increases in alkaline phosphatase, productivity, and growth of frondose algae in the presence of high nutrients (Littler et al. 1991, 1993, Lapointe 1997, Schaffelke \& Klumpp 1997, Schaffelke 2001, Thacker et al. 2001). These studies indicate that frondose algae are taking up and may be productivity-limited by phosphorus. Physiological nutrient limitation does not, however, necessarily determine nutrient regulation of algal communities (Atkinson 1988). Nutrient-mediated competitive interactions may be influential in field studies where competition is present and the most likely explanation for our observations. As a caveat, it is important to recognize that the pooling of species into functional groups may oversimplify conclusions concerning the response of taxa to nutrients as shown by our difference between the red and brown frondose algae and other species-specific studies (Thacker et al. 2001).

The RDM prediction for the low nutrient-high herbivore treatment is domination by scleractinian corals and their symbiotic algae. In this short-term study, corals survived equally well in all treatments; however, nutrients had a strong positive influence on colony coloration and algal symbiont densities after $28 \mathrm{~d}$. Paling of corals in the unfertilized cages indicated summer bleaching, which was not observed in the fertilized cages. These patterns were consistent for both species of Porites, and suggest that nutrients have the ability to mediate the bleaching response. Lack of nutrients under conditions of high temperature and/or light, as well as low water flow, may therefore contribute to a reduction in chlorophyll a concentrations to levels that are visible as bleaching. Inorganic nutrients may, therefore, play an important physiological role in compensating for temperature stress, but as described above for algae, it does not determine the regulation of coral communities, which may be more influenced by nutrient-mediated competition and possibly undiscernible or inconclusive over our short field study.

High nutrient concentrations can favor symbiotic algae over the coral host and lead to higher symbiont densities and lower coral calcification rates (Muscatine et al. 1989, Marubini \& Davies 1996, Fagoonee et al.
1999, Ferrier-Pagès et al. 2000). A reduction in calcification may reduce linear growth and competitive ability of corals that could then potentially be overgrown by algae (Tanner 1995, Lirman 2001, River \& Edmunds 2001). This overgrowth or abrasion competition is, however, most likely to occur for frondose or crustose coralline algae (McCook et al. 2001). Brown frondose algae, from our experiments, did not fare well under high nutrient concentrations, and we have observed little overgrowth of corals by crustose corallines, which are uncommon $(<2 \%$ cover) on Glover's patch reefs. Competition with filamentous and other forms of algae is more likely under high nutrient conditions, but this type of competition does not necessarily favor turf algae. One of the first direct tests of this competitive effect indicated that the massive coral Porites lobata was more competitive than turf algae under eutrophic conditions (McCook 2001). Coexistence between turf algae and scleractinian corals under high herbivory and low nutrients is a common occurrence in many coral reefs, and from our experiments, we can at least conclude that turf algae do well under these conditions.

No treatment had an effect on the symbiont community structure in these colonies, which was exclusively composed of members of Symbiodinium clade A. Molecular surveys of Symbiodinium in shallow-water Caribbean Porites have shown a predominance of clade A (Baker 1999, 2001, LaJeunesse 2002). Symbiont reshuffling has been induced experimentally in field studies of Porites astreoides and other species (Baker 2001), and indicates the potential for coral-algal symbioses to adapt to changing environmental conditions (Hoegh-Guldberg et al. 2002). Our results indicate that 'symbiont recombination' (Baker 2001) did not occur in response to increased nutrients, decreased predation, or their interaction. However, again it is possible the treatment levels and/or timescales we examined were insufficient to induce change, and future investigations should consider higher nutrient levels and longer treatment times before drawing negative conclusions.

Our experiments suggest that dominance of frondose algae on Glover's patch reefs is more likely to reflect coral mortality and low herbivory (Williams et al. 2001), rather than a response to periodic pulses of nutrients (Andrefouet et al. 2002) or nutrient levels above a threshold for eutrophication (Bell 1992, Lapointe 1997). The primary evidence is that frondose algae that currently dominate these patch reefs do not compete well in interactions with other filamentous turfs under high nutrient conditions, as shown in our experiments. Coral mortality is also not likely to occur from eutrophication, at least not over the nutrient concentrations and timescale that we studied. White-band disease may be one of the causes of coral mortality 
(Aronson et al. 2002) and resultant proliferation of algae at Glover's reef, particularly for those patch reefs once dominated by Acropora cervicornis. We have, however, recorded losses of coral and algal colonization for areas previously dominated by Porites porites and Montastraea annularis (McClanahan \& Muthiga 1998). This suggests other sources of coral mortality, such as bleaching, and less species-specific diseases, such as the White Plague (Pantos et al. 2003). Coral mortality combined with reduced herbivory resulting from Diadema mortality (Lessios et al. 1984) and removal of grazers by fishing (McClanahan et al. 2001) are the most likely causes of the ecological shift from coral to frondose algae. Paling observed in our unfertilized corals suggest that it could, ironically, be a lack of nutrient availability in these shallow, high light and low water motion areas that increased their susceptibility to coral bleaching, resulting in mortality, and eventual colonization of dead surfaces by frondose algae.

Acknowledgements. This work was supported by a joint program between the Wildlife Conservation Society (WCS) and Columbia University's Center for Environmental Research and Conservation (CERC). The Belizian Fisheries Department provided research clearance. We are grateful for the support provided by the Middle Cay Research Station. This is contribution \#17 from this field station. J. Maina helped with the statistics and preparing the figures and tables.

\section{LITERATURE CITED}

Andrefouet S, Mumby PJ, McField M, Hu C, Muller-Karger FE (2002) Revisiting coral reef connectivity. Coral Reefs 21:43-48

Aronson RB, Macintyre IG, Precht WF, Murdoch TJT, Wapnick CM (2002) The expanding scale of species turnover on coral reefs in Belize. Ecol Monogr 72:233-249

Atkinson MJ (1988) Are coral reefs nutrient-limited? Proc 6th Int Coral Reef Symp Townsville 2:157-166

Baker AC (1999) Symbiosis ecology of reef-building corals. $\mathrm{PhD}$ thesis, University of Miami, Miami, FL

Baker AC (2001) Reef corals bleach to survive change. Nature 411:765-766

Baker AC, Rowan R, Knowlton N (1997) Symbiosis ecology of two Caribbean acroporid corals. Proc 8th Int Coral Reef Symp Panama 2:1295-1300

Bell PRF (1992) Eutrophication and coral reefs - some examples in the Great Barrier Reef lagoon. Water Res 26:553-568

Belliveau SA, Paul VJ (2002) Effects of herbivory and nutrients on the early colonization of crustose coralline and fleshy algae. Mar Ecol Prog Ser 114:105-114

Bjork M, Mohammed SM, Bjorklund M, Semesi A (1995) Coralline algae, important coral-reef builders threatened by pollution. Ambio 24:502-505

Dethier MN, Steneck RS (2001) Growth and persistence of diverse intertidal crusts: survival of the slow in a fastpaced world. Mar Ecol Prog Ser 223:89-100

Fagoonee I, Wilson HB, Hassell MP, Turner JR (1999) The dynamics of zooxanthellae populations: a long-term study in the field. Science 283:843-845
Ferrier-Pagès C, Gattuso JP, Dallot S, Jaubert J (2000) Effect of nutrient enrichment on growth and photosynthesis of the zooxanthellate coral Stylophora pistillata. Coral Reefs 19:103-113

Hatcher BG, Larkum AWD (1983) An experimental analysis of factors controlling the standing crop of the epilithic algal community on a coral reef. J Exp Mar Biol Ecol 69:61-84

Hoegh-Guldberg O, Jones RJ, Ward S, Loh WK (2002) Is coral bleaching really adaptive? Nature 415:601-602

Hughes TP (1994) Catastrophes, phase shifts, and large-scale degradation of a Caribbean coral reef. Science 265: 1547-1551

Kleypas JA, McManus JW, Menez LAB (1999) Environmental limits to coral reef development: where do we draw the line? Am Zool 39:146-159

LaJeunesse TC (2002) Diversity and community structure of symbiotic dinoflagellates from Caribbean reefs. Mar Biol 141:387-400

Lapointe BE (1997) Nutrient thresholds for bottom-up control of macroalgal blooms on corals reefs in Jamaica and southeast Florida. Limnol Oceanogr 42:1119-1131

Legendre P, Legendre L (1998) Numerical ecology. Elsevier, Amsterdam

Lessios HA, Robertson DR, Cubit JD (1984) Spread of Diadema mass mortality through the Caribbean. Science 226: $335-337$

Lirman D (2001) Competition between macroalgae and corals: effects of herbivore exclusion and increased algal biomass on coral survivorship and growth. Coral Reefs 19: 392-399

Littler DS, Littler MM (2000) Caribbean reef plants. Offshore Graphics, Washington, DC

Littler MM, Littler DS (1984) Models of tropical reef biogenesis: the contribution of algae. Prog Phycol Res 3:323-364

Littler MM, Littler DS, Titlyanov EA (1991) Comparisons of $\mathrm{N}$ - and P-limited productivity between high granitic islands versus low carbonate atolls in the Seychelles Archipelago: a test of the relative-dominance paradigm. Coral Reefs 10:199-209

Littler MM, Littler DA, Lapointe BE (1993) Modification of tropical reef community structure due to cultural eutrophication: the southwest coast of Martinique. Proc 7 th Int Coral Reef Symp Guam 1:335-343

Marubini F, Davies PS (1996) Nitrate increases zooxanthellae population density and reduces skeletogenesis in corals. Mar Biol 127:319-328

McClanahan TR (1999) Predation and the control of the sea urchin Echinometra viridis and fleshy algae in the patch reefs of Glovers Reef, Belize. Ecosystems 2:511-523

McClanahan TR, Muthiga NA (1998) An ecological shift in a remote coral atoll of Belize over 25 years. Environ Conserv 25:122-130

McClanahan TR, Bergman K, Huitric M, McField M, Elfwing T, Nystrom M, Nordemar I (2000) Response of fishes to algal reductions on Glovers Reef, Belize. Mar Ecol Prog Ser 206:273-282

McClanahan TR, McField M, Huitric M, Bergman K and 5 others (2001) Responses of algae, corals and fish to the reduction of macro algae in fished and unfished patch reefs of Glovers Reef Atoll, Belize. Coral Reefs 19:367-379

McClanahan TR, Cokos BA, Sala E (2002) Algal growth and species composition under experimental control of herbivory, phosphorus and coral abundance in Glovers Reef Atoll, Belize. Mar Pollut Bull 44:441-451

McCook LJ (1996) Effects of herbivores and water quality on Sargassum distribution on the central Great Barrier Reef: cross-shelf transplants. Mar Ecol Prog Ser 139:179-192 
McCook LJ (1999) Macroalgae, nutrients and phase shifts on coral reefs: scientific issues and management consequences for the Great Barrier Reef. Coral Reefs 18: 357-367

McCook LJ (2001) Competition between corals and algal turfs along a gradient of terrestrial influence in the nearshore central Great Barrier Reef. Coral Reefs 19:419-425

McCook LJ, Jompa J, Diaz-Pulido G (2001) Competition between corals and algae on coral reefs: a review of evidence and mechanisms . Coral Reefs 19:400-417

McGlathery KJ (1995) Nutrient and grazing influences on a subtropical seagrass community. Mar Ecol Prog Ser 122: 239-252

Miller MW, Hay ME, Miller SL, Malone D, Sotka EE, Szmant AM (1999) Effects of nutrients versus herbivores on reef algae: a new method for manipulating nutrients on coral reefs. Limnol Oceanogr 44:1847-1861

Muscatine L, Falkowski PG, Dubinsky Z, Cook PA, McCloskey LR (1989) The effect of external nutrient resources in the population dynamics of zooxanthellae in a reef coral. Proc R Soc Lond Ser B 236:311-324

Pantos O, Cooney RP, Le Tissier MDA, Barer MR, O'Donnell AG, Bythell JC (2003) The bacterial ecology a plague-like disease affecting the Caribbean coral Montastrea annularis. Environ Microbiol 5:370-392

River GF, Edmunds P (2001) Mechanism of interactions between macroalgae and scleractinians on coral reef in Jamaica. J Exp Mar Biol Ecol 261:159-172

Sall J, Lehmaan A, Creighton L (2001) JMP start statistics. Thomson Learning, Duxbury

Schaffelke B (2001) Surface alkaline phosphatase activities of macroalgae on coral reefs of the central Great Barrier Reef, Australia. Coral Reefs 19:310-317

Editorial responsibility: Otto Kinne (Editor),

Oldendorf/Luhe, Germany
Schaffelke B, Klump DW (1997) Growth of germlings of the macroalga Sargassum baccularia (Phaeophyta) is stimulated by enhanced nutrients. Proc 8th Int Coral Reef Symp Panama 2:1839-1842

Smith JE, Smith CE, Hunter CL (2001) An experimental analysis of the effects of herbivory and nutrient enrichment on benthic community dynamics on a Hawaiian reef. Coral Reefs 19:332-342

Steneck RS (1983) Escalating herbivory and resulting adaptive trends in calcareous algal crusts. Paleobiology 9:44-61

Steneck RS (1997) Crustose corallines, other algal functional groups, and herbivores: complex interactions along reef productivity gradients. Proc 8th Int Coral Reef Symp Panama 1:695-700

Stimson J, Larned ST, Conklin E (2001) Effects of herbivory, nutrient levels, and introduced algae on the distribution and abundance of the invasive macroalga Dictyosphaeria cavernosa in Kaneohe Bay, Hawaii. Coral Reefs 19:343-357

Tanner JE (1995) Competition between scleractinian corals and macroalgae: an experimental investigation of coral growth, survival and reproduction. J Exp Mar Biol Ecol 190:151-168

ter Braak CJF, Smilauer P (1998) CANOCO reference manual and user's guide to Canoco for Windows: software for canonical community ordination (version 4). Microcomputer Power, Ithaca, NY, p 352

Thacker RW, Ginsburg DW, Paul VJ (2001) Effects of herbivore exclusion and nutrient enrichment on coral reef macroalgae and cyanobacteria. Coral Reefs 19:318-329

Williams ID, Polunin VC, Hendrick VJ (2001) Limits to grazing by herbivorous fishes and the impact of low coral cover on macroalgal abundance on a coral reef in Belize. Mar Ecol Prog Ser 222:187-196

Submitted: December 17, 2002; Accepted: August 5, 2003 Proofs received from author(s): October 13, 2003 